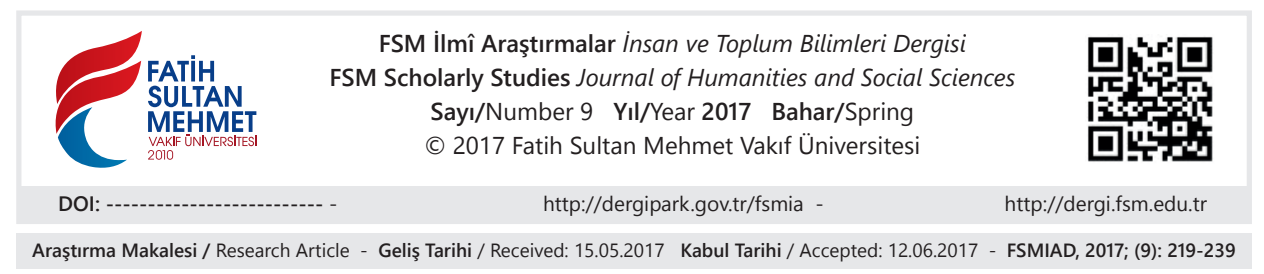

\title{
İnsanın Kentinden Kentin İnsanına: Öyküde Kent, Kentleşme, Kentlileşme Görünümleri
}

Bekir Hergüner*

\section{$\ddot{O} \mathbf{z}$}

İnsan zaman ve mekân algısıyla kuşatılmışıı. İnsan yapıp ettikleriyle mekânda kalıcı izler bırakmakta, zamanın aynasında bu izler takip edilmektedir. Mekân kurmanın ifade şekillerinden birisi olan kentleşme ve mekâna uygun davranış geliştirme anlamına gelen kentlileşme kavramları modernleşme ile birlikte dolaşıma giren kavramlardandır. Ülkemizdeki kentleşme ve kentlileşme pratiklerinden geleneğin şehirleri olumsuz bir biçimde etkilenmiştir. Öykü tür itibariyle insan gerçekliğini merkezine alır. Kentleşme ve kentlileşme de, modern insanın gerçekliğidir. Özellikle 1950'lerde başlayıp hız kesmeden devam eden kentleşme, kentlileşme hareketleri ve insanın durumu birçok öyküye konu olmuştur.

Anahtar Kelimeler: Kent, kentleşme, kentlileşme, insan, öykü.

\section{From Human's City to City's Human: City, Urbanization and Views of Urbanizing}

\section{Abstract}

Humanity is caught up in perception of time and space and it leaves permanent traces in space through his deeds and actions. These traces can be pursued via the mirror of time. Urbanization, which is a form of expressing creation of a space, and urbanizing, which means human beings' developing new attitudes and behaviours according to a new space, are the two terms which were introduced by modernism. The traditional cities have been adversely impacted by urbanisation practices in Turkey and also urbanizing. Characteristically, story is based on reality of humanity. Furthermore, urbanisation and urbanizing have become the realities of modern men. Starting particularly in the 1950s, urbanisation has continued to progress without a pause and has become a subject matter along with humanity and its urbanising ways.

Keyyords: City, urbanization, urbanize, human, short story.

* Doktora Öğrencisi, Fatih Sultan Mehmet Vakıf Üniversitesi Sosyal Bilimler Enstitüsü Türk Dili ve Edebiyatı Anabilim Dalı, İstanbul/Türkiye, hergunerb@gmail.com 


\section{Giriş}

Mekân, insanın bütün eylemlerini gerçekleştirdiği alandır. Mekân olgusu bir yere karşı1ık gelmesi yönüyle coğrafya ile ilintilidir. Bu açıdan bakılırsa mekânın bir yönüyle doğal, başka yönlerden bakıldığında da sosyal, ekonomik ve politik süreçlerin bir parçası olduğu gerçeği ortaya çıar.

İnsan, doğumundan ölümüne mekânla kuşatılmıştır. Ev, semt, mahalle, köy, kasaba, kent, ülke ve dünya, insanı kuşatan mekânın niteliği farklı katmanlarıdır. David Harvey için mekân, insanı biçimlendiren ve onun tarafından biçimlendirilen toplumsal bir boyuttur. ${ }^{1}$ İnsan davranışları, davranışların toplumsal süreçlere dahil olup kimlik, kişilik kazanması belli bir mekânda gerçekleştiği için o mekândan etkilenmektedir. İster bireysel olsun ister toplumsal bütün davranışların mekân düzleminde bir karşılığı vardır. Mekân olmadan davranışları bir kategoriye sokmak, anlamlandırmak mümkün değildir.

İnsanın var oluşu anlamına gelen mekânsal süreç başlangıçtaki ilk toplanmalardan itibaren kentsel yerleşimlere işaret eder. Çünkü kentin varlığı bir sistemin, bir düzenin varlığını gerektirir. İnsanoğlu kendisine, çevresine mekân olarak kent inşa ederken aynı zamanda medeniyeti de inşa etmiştir. Her medeniyetin mekân kurma biçimi, bunu kentsel göstergeler haline getirme biçimi farklı1ık gösterir. Medeniyeti ortaya çıkaran etkenler, kurucu değerlerin, taşıyıcı kolonların farklılığı kentsel yapılara da yansır. Kimi kentlerin ortaya çıkışında din ve hukuk etkin konumda iken kimi kentlerde ise ekonomi veya güvenlik ön plana çıkar. Ancak kentlerin oluşumunda görülen bu farklılık, sanayi devrimi ile birlikte aynılığa dönüşmüş ve sosyo-ekonomik süreçler kentleri ortaya çıaran yegâne belirleyiciler olmuştur. Medeniyet, mekân üzerinde kurulur, maddi göstergelerini mekân üzerinden insanlığa sunar. Göstergeleri en açık, en düzenli, en kapsamlı halde sunan ise kent mekânlarıdır. Bu bağlamda bir kentte ve bu kentin bileşenleri olan bir evde, bir mabette, bir çarşıda insana ait bir davranış kalıbının, bir medeniyetin izdüşümleri okunabilir.

Mekânlar içinde bulundukları kaba göre şekil alırlar, varlık kazanırlar. Medeniyet şekil veren kap hükmündedir. Mekân dediğimiz olgu medeniyet kabında şekil alıp ete kemiğe bürünür.

Batı kentleri, Batı medeniyetinin, İslam kentleri İslam medeniyetinin değerlerine, geleneğine, var oluş biçimine dair ipuçları barındırır. Bir medeniyetin kentlerinden o medeniyetin neye, ne kadar önem verdiği veya vermediği, neyi önceleyip öncelemediği çıkarılabilir. Geleneksel şehri, bu şehirdeki yaşantıyı ortaya çıkaran İslam medeniyeti ve tasavvuru olduğu gibi modern kenti ortaya çıkaran da Batı medeniyeti ve tasavvurudur.

1 David Harvey, Sosyal Adalet ve Şehir, Metis Yayınları, İstanbul, 2003, s. 11. 


\section{Kent, Kentleşme, Kentlileşme}

"Descartes'in res cogitans [düşünen şey, düşünen varlık] olarak tanımladığ1 insan ile res extensa [yer kaplayan şey, yer kaplayan varlık] olarak tanımladığı dünya"'da modern kent anlayışı, sanayileşmenin görünür kıldığ1 ve modernliğin biçimlendirdiği hayat anlayışından doğmuştur. "17. yüzyılda doğa bilimleri ile birlikte ortaya çıkan, siyasi doruğuna 18. yüzyıl devrimleri ile ulaşan ve genel implikasyonların 19. yüzylldaki Sanayi Devrimi'nden sonra sergilemeye başlayan modern çăg "’3 kent anlayışını tamamen değiştiren etken olarak görünmektedir. Modernliğin kendisini daha önceki anlayışlardan, toplumsal oluşumlardan ayırış1 tam bir kopma ve keskin dönüş halidir ve bu kopma ve keskin dönüş hali son iki yüz y1llık süreçte gerçekleşmiştir. ${ }^{4}$ Modern hayat kendi kavramları ve kurgusu içerisinde tüm göstergeleriyle modern kent imgesini yaratır. "Bu bağlamda "modern kent" olgusu, "geleneksel şehir" kavramı ve varlığ ile bir karşıtlık ve yıkıcılık ilişsisi içinde, geleneksel şehirlerin ruhunu ve bu ruhu teşkil eden inanç ve yaşama biçimlerini zedeleye zedeleye, kazıya kazıya varlığını ikame etmiştir." 5

Sanayi kentine gelinceye kadarki süreçte üretim biçimlerinin farklılaşmamasıyla da bağlantılı olarak kent anlayışında büyük değişimlerin yaşanmadığı görülür. Sanayi Devrimi üretim ilişkilerini etkilemiş, üretim ilişkilerinin değişimi de kent yaşamında, köklü değişimlere, kırılmalara kapı aralamıştır. Kırılma döneminde yaşanan değişim ve dönüşümü modernleşme ve kapitalizm ile açıklamak mümkündür. Sanayileşme öncesinde kentlerin daha çok inanç, güvenlik ve pazar eksenli biçimlendirildiği, modernleşmenin ve üretim ilişkilerinin farklılaşmasından doğan kapitalizmin başat rolde olduğu kentlerin ise kurumlar, bulvarlar, ulaşım ağları eksenli biçimlendirildiği görülür. Sanayi devrimi ile kapitalizm, kentlerin devasa ölçeklerde büyüyüp gelişmesine öncülük ederken, yeni ulaşım ve kitle iletişim araçlarının ortaya çıkışını da kolaylaştırmıştır. Geçmişe ait geleneksel değerlerin ve insanın kendi gerçekliğiyle ilgili algıların da ters yüz olduğu bu dönemde, hem kentler hem de gündelik hayat değişmiştir.

Sanayileşmeyle birlikte ilk işaretleri ortaya çıkan kent, David Harvey'e göre "kuşkusuz karmaşık bir şeydir." Kentin bizzat kendisi belirsizliği, tekinsizliği, kuşkuyu artırdığı için karmaşıktır. Kentleşme, kentlerdeki nüfusun, yerleşimlerin

2 Hannah Arendt, Geçmişle Gelecek Arasında, çev. Bahadır Sina Şener, İletişim Yayınları, İstanbul, 1996, s. 58.

3 A.g.e., s. 43.

4 Hakkı Yırtıcı, Çağdaş Kapitalizmin Mekânsal Örgütlenmesi, İstanbul Bilgi Üniversitesi Yayınları, İstanbul, 2005, s. 2.

5 M. Fatih And1, "Beton Duvarlar Arasında Açan Çiçek: Modern Kent ve Kentleşmeye Karşı Erdem Beyazıt'ın Şiiri”, FSM İlmî Araştırmalar İnsan ve Toplum Bilimleri Dergisi, Sayı: 1 Y1l: Bahar 2013 (79-92), s. 81.

6 David Harvey, a.g.e., s. 27. 
artması demektir; kentlileşme ise kente uygun davranışlar geliştirme anlamına gelir. Kent gerçeğinden hareketle var olan kentleşme ve kentlileşme olguları da bu kaotik yapıyı besleyen aktörler konumundadır.

Sosyo-ekonomik süreçlerin etki alanı toplumsal yapılardan başkası değildir. Ekonomik hayat, siyasi ve sosyal hayat bu süreçlerden ne ölçüde etkileniyorsa insan da, kültürel unsurlar da, sanat ve edebiyat da o ölçüde etkilenir. O sebeple sanat ve edebiyattaki değişimi, yeni türlerin ortaya çıkışını bu etkenlerle birlikte okumak gerekir. Sanatın, edebiyatın, siyasetin değişimi toplumsal yapılardaki değişimin aynasıdır. Batıda romanı ortaya çıkaran süreç, feodalitenin etkinliğinin azalması ve sanayileşme ile doğumuna tanık olunan kent, işçi, emek ve burjuva sınıfı gibi aktörlerin devreye girmesidir. Roman gibi öykü de (short story) bu süreçlerden etkilenen türlerdendir. Öyküdeki kısalık, yoğunluk, vuruculuk, bir oturuşta bitirilme gibi özellikler, zamanın fazlasıyla öne çıkarılıp değerli hale getirildiği sanayi toplumunun özellikleriyle örtüşür.

\section{Türk Öykücülüğünde Kent, Kentleşme ve Kentlileşme}

Modern Türk edebiyatının başlangıcı ve gelişimi de sosyal-siyasal gelişmelerden ayrı düşünülmemelidir. Çünkü sosyal yaşantısında derin ve büyük kırılmalar yaşayan toplumlar bu durumu anlatacak araçları da ortaya koymuşlardır. Hem gazetenin, hem romanın, hem de öykünün edebiyat sahnesine çıkışına bu şekilde bakmak gerekir. Toplumsal değişme ve öykü ilişkisini değerlendirdiği yazısında Köksal Alver, "genel anlamda Türk edebiyatı özelde öykü, toplumsal değişimin izlenmesi ve analiz edilmesi sürecinde önemli veriler sunmaktadır. Türk öyküsü, Türk toplumunun temel dinamikleri, yapısl, unsurlart, kurumları ve değerlerinde olduğu gibi değişim süreci, değişim dinamikleri ve aktörleri ile de doğrudan ilgili olmuştur." "1796-97'de yazılan Muhayyelat-ı Aziz Efendi ve 1872-1875'de yazılan Müsameretname, 1870-1895'te yazılan Letaif-i Rivayat gibi öykü türünün ilk örneklerinde yer yer geleneksel tahkiye anlayışının izleri görülse de onun devamı olmaktan uzak oldukları anlaşı1ır. Bu örneklerde, içerik kısmının geleneğin devamı olmakla birlikte özellikle öykü tekniği bakımından Batıdaki örneklerinden yola çıkılarak oluşturulduğu izlenimi vardır. Bu konuda Tanpınar'ın ilk dönem hikâye örneklerinin niteliği ile ilgili tespitleri önemlidir: "Bu ilk tecrübelerde ne psikoloji, ne canlı karakter, ne de etraftaki hayatı canlandirmak endişesi yoktur. Fakat, vak'anın tertip şekli, kahramanlarla etraf arasında kurmak istenilen alâkalar, hadiseler üzerinde duruş tarzı ve bazı müşahede sizıntıları ile eski hikâyelerden de çok ayrılırlar."

7 Köksal Alver, “Toplumsal Değişme ve Öykü”, Hece Öykü, Yı1:2 Sayı: 12 Aralık-Ocak 2005, s. 60. (59-67)

8 Ahmet Hamdi Tanpınar, "Hikâye ve Roman", 19'uncu Asır Türk Edebiyatı Tarihi, Çağlayan Kitabevi, İstanbul, 1997, (285-297), s. 289. 
Öykü ve anlatıya dayalı diğer türler, bir mekâna yaslanarak gerçeklikle bağ kurar. Öyküde hayatın kendisine, yani yaşananlara, hayal kırıklıklarına, sevinçlere, hüzünlere mekânla yaklaş1lır. Dile dökülemez, tarif edilemez bir duygu mekânın kendisiyle veya bir mekânsal öge ile kolaylıkla ifade kalıbına dökülüverir.

Modern Türk edebiyatının başlangıcı kabul edilen Tanzimat döneminde öykü ve roman türünün ilk örneklerinin mekânları genellikle kentlerdir. Ancak kente ait ayrıntılara, insan üzerindeki etkilerine, insanda uyandırdıklarına çok fazla değinilmez. Kent, öykünün merkezi, bir problem alanı olarak görülmez. Kent, mekâna dair ipuçları veren bir dekordan fazlası değildir. Mekân, özellikle de kent mekânları, öykü veya roman bir zemine otursun diye vardır.

Tanzimat dönemi öykü ve romanı için birer dekor olan kentler, aynı zamanda yaşam merkezleridir. Ancak bu yaşam merkezleri, Batıda olduğu gibi işçi sınıfının kırsaldan bütünüyle koparak kentlere yığılması sonucunda ortaya çıkmamışlardır. Batıdaki toplumsal hareketlilik, sınıf çatışması, kent gerçeğinin günden güne değişimi, kentleşmenin acımasızlığ 1 , kentlileşen insan profili Osmanlı toplumunda hiçbir anlam ifade etmemektedir. Osmanlı toplumu, sanayileşmeyle henüz tanışmadığı için ne işçi ne de burjuva sınıfını teşekkül ettirebilmiştir. Dolayısıyla Türk öyküsü kaynağını kentlerde doğup büyüyen burjuvaziden almaz ancak mekân bağlamında adeta kent öyküsü karakteri taşır. Tanzimat dönemindeki ilk öykülerden itibaren öykünün baş ve biricik mekânı, hem kentli yaşam tarzının en gelişmiş örneğini sunması, hem de modernleşmenin ilk etkilerini yansıtması açısından İstanbul olur.

Servet-i Fünun ve Milli Edebiyat dönemlerinde de öykü ve roman mekânlarının kentler olarak seçilmesi durumu değişmez. Cumhuriyet dönemi öykü ve romanında halkçı1ık anlayışının bir yansıması olarak köye, köylüye doğru bir yönelmenin geliştiği gözlenir. Bu sebeple mekân az da olsa farklılaşmıştır; öykülere kent yerine köy ve kasaba yerleştirilmiş, buradaki insan gerçeğinden hareket edilmiştir. Fakat mekâna, mekânın insan üzerinde bıraktıklarına dair derinlikli, kuşatıcı bir tahlil geliştirilememiştir. Memleket Hikâyeleri ile Refik Halit, daha sonra toplumcu çizgide, Anadolu damarı ağır basan kasaba hikâyeleriyle Sabahattin Ali örnekleri bunun dışındadır.

1930 sonrası öykü iki koldan ilerler. Birincisi, Refik Halit'in başını çektiği sosyal muhtevaya önem veren, Anadolu meselelerini önceleyen koldur. Sabahattin Ali öykücülüğü de bir yönüyle bu kola dahil edilebilir. İkincisi ise, Sait Faik' in başını çektiği birey eksenli, kentin göze batmayan küçük insanının merkeze alındığ1 koldur. Denilebilir ki kentin, kent insanın öykünün eksenine oturması Sait Faik'in anlattıklarıyla gerçekleşir.

1940-50 yılları arasında kentli nüfusun artış hızı ile kentleşme hızı doruğa çıkar. 1950-60 arasında kentleşme hızının katlanarak artışı söz konusudur. Elbette ki hem kentli nüfusun artış hızı hem de kentleşme hızı yaşanan sosyal bir 
gerçekliktir. Ve bu gerçekliğin toplumsal ve kültürel alanda bir karşıllığ1 mutlaka olacaktır. Kent, kentleşme, kentlileşme olgularının öyküye yansımaları 1950'lerle birlikte gün yüzüne çıkar. Kentsel mekânların sorunları, kentli bireyin yabancılaşması, hızlı ve çarpık kentleşme, kente uyum sağlayamama gibi izlekleri öyküler üzerinden okumak mümkün olur. Bununla birlikte "ekonomik sıkıntılar, sınıfsal yapı, toplumsal tabakalar arasındaki uçurumlar, çatışmalar, büyük kentin birey üzerindeki etkileri, bunalımlar, yalnızlaşma, gecekondulaşma, varoş olgusu birçok öykücünün dikkatinden kaçma[mıştır]" "görülür.

Sanayileşme, kente olan ilgiyi artırarak nüfus ve yerleşim anlamında kentlerin çehresini değiştirmiştir. Sanayinin kurulduğu alanlar nüfus olarak kalabalıklaşmış, gecekondu bölgeleri adı verilen yeni yerleşim mekânları birey gerçekliğinden hareket eden öykücüler için zengin bir kaynak oluşturmuştur. $\mathrm{Bu}$ yeni yerleşim mekânları, içinde yaşayan insanları etkilemekle kalmamış, aynı zamanda genelde sanat, özelde ise öykü için bir beslenme kaynağı olmuştur. $\mathrm{Bu}$ bağlamda şehir, bazı çatışmaların zemin bulduğu mekân olarak da değerlendirilir. Şehirdeki çatışma zemininin aktörleri ise şehre tutunma çabasındaki küçük insanlardır. Öykülerde geleneksel ile yeni değerler arasında gelgitler yaşayan bu küçük insanlar önemli roller üstlenirler.

1950'lerde, Sait Faik etkisinin fazlasıyla hissedildiği, bireyin, iç dünyas1nın, bunalımlarının merkeze alındığı öyküleri ve bunları kaleme alan öykücüleri görürüz. Edebi esere yansıyan gerçeklik bir bakıma hayatın gerçekliğidir. Dolayısıyla bireyin bütün boyutlarıyla ortaya çıkışının arka planında İkinci Dünya Savaşının yıkıcı, psikolojik ve sosyolojik etkilerini, varoluşçuluğu, kentleşmeyi, köyden kente göç furyasının başlangıcını görmek mümkündür.

1950 kuşağı öykücüleri, bireyin bunalımlarını, iki dünya savaşının ardından oluşan kaotik yapıyı, karamsarlığı, yabancılaşmayı, entelektüel krizleri, hayatın anlamsızlığını, bakir bir alan olan cinselliği, hiçlik duygusunu, bunalımı yeni mekân algisıyla ilişkilendirerek okuyucuya verirler.

1950'li y1llarda çeşitli sebeplerle fitili ateşlenen yoğun nüfus hareketliliği, 60'lı yıllarda da hızını kesmemiş hem bireyi, hem de toplumsal yapıyı değiştirmeye devam etmiştir. Kırsalın hızla boşalmasına karşılık kentler insan ve konut anlamında hızla dolmaya başlar. Kente gelenlerin sayısı ve bu sayının oluşturduğu sorunlar arttığ 1 ve değiştiği için 1950 kuşağ öykücülerinin Sait Faik etkisiyle başlayan bireye eğilme sürecinde de çeşitlenme artar. Olcay Önertoy, 1960'l1 yıllarda toplumsal konuların yanında bireye önem verilmeye başlandığını, öykücülerin, çevresiyle uyum sorunu yaşayanları, yaşanılan zaman dilimindeki düzene karşı uyumsuzluğu kendilerine konu edindiklerini söyler. ${ }^{10}$

9 Köksal Alver, “Toplumsal Değişme ve Öykü”, Hece Öykü, Sayı: 12 Y11: Aralık-Ocak 2005 (59-67), s. 61.

10 Olcay Önertoy, Cumhuriyet Dönemi Türk Roman ve Öyküsü, Türkiye iş Bankası Kültür Yayınları, İstanbul, 1984, s. 311. 
$\mathrm{Bu}$ dönemde yazılan öykü ve romanlarda yansıtılan kentleşme olgusuyla ile ilgili Sevinç Özer, Türk roman ve kısa öyküsünde kentleşmenin başlıca iki aşamasını görmenin olası olduğunu söyler; bu aşamalardan birincisi kırdan kente göç edenlerin yaşadıkları kültür şoku ve buna bağlı uyum sorunlarının ele alındığ1 roman ve kısa öyküler, ikincisi ise ekonomik göstergelere paralel gitmeyen kentleşme ve kentlileşmenin insan üzerindeki olumsuz yansımalarının anlatıldığ roman ve kısa öyküler. ${ }^{11}$

1970'li yıllarda 50 ve 60 anlayışın dışında Necip Fazıl çizgisini devam ettiren bir öykü anlayışıyla karşılaşırız. Necip Fazıl'ın Kaldırımlar şairinden Çile'nin şairine dönüşme süreci, giderek Allah, kader, ölüm, metafizik gibi sırrî olana doğru yönelen bir süreçtir. Sürecin yansımaları hikâyelerinde de ön plana çıkar. Sezai Karakoç, Rasim Özdenören, Mustafa Kutlu, Cahit Zarifoğlu gibi isimler Necip Fazıl'ın başlattığı İslamî duyarlılık çevresinde toplanan isimlerdir.

Sezai Karakoç çerçevesini kendisinin çizdiği Diriliş çizgisinde iki büyük dünya savaşı neticesinde insanın içine düştüğü bunalımı, inançsızlığ1 anlattığ1 Hikâyeler I (1978) ve Hikâyeler II (1982)‘deki girift, kıssa damarı olan hikâyeleri ile bu duyarlılığı devam ettiren isimlerin başında gelir.

Rasim Özdenören, öykü serüvenine Hastalar ve Işılklar (1967) adlı kitabıyla başlar. Özdenören öyküleri, Foulkner, Dostoyevski, Heidegger etkisinin fazlastyla hissedildiği, modern toplum içinde bunalan insanlar, modern insanın çelişkileri, inanç, aşk, metafizik, tasavvuf temalarını işleyen, yer yer postmodern tekniklere de başvurulan ve giderek kısalan ama vuruculuğu artan öykülerdir.

Mustafa Kutlu'nun, Ortadaki Adam'la (1970) başladığı hikâyecilik serüveninde daha evvel Anadolu damarını yakalamış olan Sabahattin Ali, Nurettin Topçu isimlerinin etkisini görürüz. Ortadaki Adam, Gönül İşi ve Yokuşa Akan Sular hikâyelerinde Anadolu eksenli, köyden kente göçün sıkça vurgulandığı, kent ve kentleşme karşısında yabancılaşan, değersizleşen, modern ve geleneksel değerler arasında bocalayan kahramanların yalın, vurucu olayları anlatılır. Yokuşa Akan Sular ve Yoksulluk Iç̧imizde hikâyelerinde yer yer tasavvufun remizler dünyasına yönelme izlekleri belirginleşir.

Mustafa Kutlu'nun neredeyse tüm hikâyelerinde geleneksel hayat ve karş1sinda kent, kentleşme, kentlileşme problemi bir şekilde dile getirilir. Ortadaki Adam, Gönül İşi, Yokuşa Akan Sular, Bu Böyledir, Chef, Beyhude Ömrüm, Huzursuz Bacak vd. gerek anlatıcı, gerek kahramanların ağzından kent, kentleşme, kente ait davranışlar yerilirken, insan ve toplumun yapıcı unsuru olması nedeniyle geleneksel değerler yüceltilir. Modern kent olgusu, insanı bozan, aslından uzaklaştıran yanlarıyla sorunun kaynağı olarak yansıtılır. Modern kent hayatı in-

11 Sevinç Özer, “1960“tan Bu Yana Roman ve Kısa Öyküde Kentleşme Olgusu ve Kentlileşme Sorunlar1”, Yazko Edebiyat, Say1: 32 Y11: Haziran 1983 (88-100), s. 90-91. 
san için sürekli çözümsüzlük üretmektedir. Çözüm öze, yani geleneksel değerlere dönüşle mümkündür.

1970'lerde Rasim Özdenören, Mustafa Kutlu ile başlayan çizgide hem kırdan kente göç olgusu, kültür şoku ve uyum sorunları hem de yaşanan hayatla uyuşmayan kentleşme, kentlileşme meseleleri çarpıcı bir biçimde ele alınır.

1980'lerden 2000'lere, 2000'lerden günümüze uzanan dönemde hem Özdenören'i, hem Kutlu'yu hem de onlara katılan Hüseyin Su, Sevinç Çokum, Emine Işınsu, Cemal Şakar, Cihan Aktaş, Fatma Karabıyık Barbarosoğlu ve diğer birçok ismin aynı duyarlılıkla yazılan öykülerine tanık oluruz.

\section{Türk Öykücülüğünde Kent, Kentleşme ve Kentlileşme Görünümleri}

Türk toplumu, 1950 öncesinde gelirlerinin çoğu tarıma dayalı ve nüfusunun büyük çoğunluğu kırsalda yaşayan insanlardan oluşan bir toplumdur. 1950 sonrası tarımda makinalaşma ve sanayileşme hamleleri insanların yönünü yavaş yavaş kırdan kente doğru çevirmiştir. Mübeccel Kıray'ın da vurguladığı, "Türkiye gibi geç sanayileşen toplumlarda yüzyılın ikinci yarısina damgasını vuran gelişme, köylülüğün çözülmesi ve topraktan kopan insanların kentsel alanlara göçüdür."12 $\mathrm{Bu}$ durumun edebiyata ve özünde kentli bir tür olan öyküye yansımaları elbette olmuştur. Başta 1950 kuşağı öykücüleri olmak üzere kentleşme furyasının başladığ 1 andan günümüze kadar bu yansımalar öyküde modern insanın problemi olarak daima ilgi görmüştür.

Gelenek uzun zamanın birikimlerini ifade eden bir yapı olduğu için hayat tarzımızın çerçevesini çizen en önemli unsurdur. Dünyayı gelenek çerçevesinde açıklayan anlayışa göre, geleneksel dünya yine kendisine ait bilgilerle açılanabilir. Bu bilgi, "varlık"ın hakikati de içkin olan bilgisidir. Varlık bilgisi ise, iki temel üzerinde yükselir. İlki "vahiy"dir ve Tanrı bilgisine işaret eder, ikincisi de evrende olup bitenler yoluyla edinilen tecrübî bilgidir. Geleneğin dünyasında insan, eşya ve tabiata bu iki bilgi ile kuşatılmanın özgüveni ile bakar. İnsanın medeniyet kurma girişiminde merkezi bir noktaya oturan şehir, hayat tarzımızı yansitan en önemli sembollerdendir. Geleneğin medeniyeti ve bu medeniyetin şehirleri insanın varlıkla yani hakikatle olan ilgisi çerçevesinde ele alınıp biçimlendirilmiştir. Dolayısıyla böylesi şehirlerin bağrında hakikati dışlayan, eşyaya ve tabiata yabanc1 etkilerin barınması zordur.

Geleneksel kent kurulurken semtler ve mahalleler aracilığıyla varlık alanında yayılma imkânı bulur; modern kentler ise toplu konutların, toplu yaşamların varlık alanıdır. Geleneğin kentlerinde farklı hayatlar ve kimlikler semtle, mahalleyle birbirlerine bağlanırken; modern kentlerde aynı hayatlar ve kimlikler toplu konutla, site ile birbirine bağlanır. Bu yaşam formlarından geleneğin

12 Mübeccel Kıray, Kentleşme Yazıları, Bağlam Yayınları, İstanbul, 1998, s. 184 
kenti bilinirliğe, tanınırlığa, beraberliğe, bağlılığa vurgu yaparken, modernitenin kenti anonimliğe, ayrilığa, çoğulluğa, melezliğe vurgu yapar. Bu vurgu küreselleşmenin çizgileri ile örtüşen bir vurgudur. Küreselleşme, yani bütün dünyayı global bir köy haline getirme düşüncesi, soğuk savaş dönemlerinde kalın çizgilerle çizilen sınırların belirsizleşmesi, ortadan kalkması, her yerin aynılaşması bir anlamda mekânsızlaşması demektir. Mekânsızlaşmanın şu zamandaki karşı1ığı küreselleşme, küreselleşmenin gereği de hızla metropolleşen kentlerdir. Metropol kent denilerek ortaya çıkarılan mekânsal yerleşim, en son teknolojinin kullanılarak geleneksel kent anlayışının kırıldığı, belli bir disipline bağlı olmayan, kalabalık kent merkezlerindense birden fazla merkezi olan, daha az yoğun, parçalı bir yapı özelliği gösteren yaşam alanlarının oluşturduğu bir kent ve onunla koşut hareket eden bir yaşam biçimini teklif etmektedir. ${ }^{13}$ Teklif edilen yaşam biçimi ise insanda yersizlik yurtsuzluk duygusunu körükleyecek olan, her yerin ve herkesin aynılaştığı bir yaşam biçimidir. Mustafa Kutlu, Nur hikâyesinde geleneksel yerleşim tarzıyla modern yerleşim tarzını şu cümlelerle karşılaştırır: "Eskiden her mahallenin kendine ait hususi bir havası, bir tarz-ı hayatı vardı. Şimdi ise birbirinin kopyası aynı tipte, soğuk, cansız binlerce apartman, ruhsuz, beton kütleleriyle bütün şehirleri aynîleştirmiş, şehirlerin, mahallelerin ruhu yok olmuştur. Artık her yer aynı ve hiç kimse bir yere ait değil." ${ }^{14}$

Geleneksel şehrin yerleşiminde Türk-İslam medeniyetinin mimari anlayışını yansıtan küçük bir meydan, meydanın etrafına sıralanan dükkânlar, meydanın bir yanında cami ve caminin bahçesinde bir türbe şeklinde semboller vardır. Geleneksel anlayışta tabiat, savaş açılacak, tekrar tekrar üretilecek bir unsur değildir. Yaşamın olmazsa olmaz parçalarındandır. Geleneğin mekânlarında zaman "yekpare geniş bir an" olur ve "parçalanmaz akış"la akar ve sakinlerine huzur verir. Geleneksel şehirde insan, kendisine hitap etmeyen kentleşmenin girdabındaki kentlerden kaçarak kesin bir yargıla "ancak burada yaşayabilirim" der. Cemal Şakar'ın Ihtilaç öyküsü de böyle bir kent betimlemesiyle başlar:

"Küçük bir meydan;

meydanın etrafına sırlanmış dükkanlar;

meydanın bir yanını çevreleyen bir cami;

caminin avlusunda bir türbe;

türbeyi çevreleyen hazire;

cami ve meydanı aydınlatan sarı lambalar;

sarı lambalar ve hafif sisin kattığı gizem;

ancak böyle bir yerde yaşayabilirim, diye düşündüm otobüsten inerken." ${ }^{15}$

13 Hakk1 Yirtıc1, a.g.e., s. 10.

14 Mustafa Kutlu, Nur, Dergâh Yayınları, İstanbul, 2014, s. 84-85.

15 Cemal Şakar, "İhtilaç”, Hece Öykü, Sayı: 1 Yı1: Şubat-Mart 2004 (30-33), s. 30. 
İnsanın inşa ettiği, medeniyet tasavvuruna göre biçimlendirdiği kent yoktur artık. Modernitenin, kapitalist gerçeklerin başat rol oynadığı kent, insanın "hem doğduğu hem de öldüğ̈̈ yer" "dir. Kent üretilen, tüketilen, sonra yeniden üretilen modernist ve kapitalist mekân anlayışının yansımasından ibarettir.

Rasim Özdenören'in Şimdi Çok Uzaklarda hikâyesinde kent imgesi kırsaldaki insan için "her şey(in) güzel olacağı yerdir". Çok iyi yaşamak için kente gitmek elzemdir. İnsanların akın akın kente gelme sebeplerinin başında "her şey çok güzel olacak" mottosu yatmaktadır. Hikâyenin devam eden cümlelerinde kent hayat1-

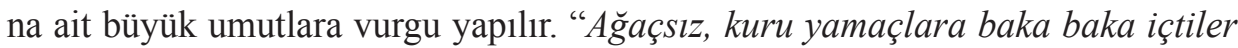
çaylarını. "Güzel olacak" diyordu Yakup "her şey güzel olacak. Bir manav dükkânı açacağım kentte. Kendi başımıza.. kimseye yük olmadan.. belki paramız bile olacak.. kendi paramız.. bayramda hediye göndeririz ananlara. Babana bir çift ayakkabı göndereceğim, gömlek bile alacağım. Sana ne istersen alacağız. Kendi başımıza buyruk. Çok iyi yaşayacağız, anlıyor musun?"'17

Kentin modernleşme ile değişen çehresine bakıp "Ne oldu bu şehre birdenbire?" diye soran kahraman, eski geleneksel yaşama dair referanslarla kendisini ayakta tutmaya çalışır. Mustafa Kutlu'nun Bir Mektup hikâyesinde şehrin değişimi ve acımasız kentleşme şu satırlarla verilir:

"Ne oldu bu şehre birdenbire? Yerden biter gibi vahşi binalarla doldu. O güzelim asmalı kahvenin yerinde şimdi yeller esiyor. Her gün sulanıp süprülen, akşam serinliğinde bir ıslak toprak kokusu ile karışık, zümrüt gibi salatalık, tere, maydanoz; icabı halinde kavun, karpuz, sırık domatesi lüks lâmbası 1şıları altında efsanevî görünüşleri ile pırıl pırıl manavlar. Faytoncu durakları, seyyar esnaf tablacılar. Silindi. Hem de farkında olamadan. Arsalar borsalar yüz binlere firladı. Her köşe başında, gözlerinde siyah bant taşıyan bir emlâkçi peyda oldu. Her sokaktan, pardon, her mahalleden bir milyoner fişkırır oldu... ${ }^{18}$

Kentleşme, kentin nüfus ve bina bakımından yoğunlaşması demektir. Kentleşme bir plan, program dahilinde yürütülmediği için, her yerden inşaatlar yükselmekte, her önüne gelen müteahhit olmakta, her kapının "önüne bir Mercedes çekil"mektedir. Ve bu inşaatlar Kutlu'nun anlatımıyla "Kuzeyin barbar kavimle$r i$ ”nin Avrupa'yı istilası gibi kentleri istila etmektedir:

"Bu şehri inşaatlar istilâ etti. Kuzeyin barbar kavimleri gibi, putrelleri, tuğla-

16 Besim F. Dellaloğlu, "Kent Öznenin Evidir”, 21. Yüzyıl Karşısında Kent ve İnsan, Yayına Hazırlayan: Firdevs Gümüşoğlu, Bağlam Yayınları, İstanbul, 2001, s. 73.

17 Rasim Özdenören, "Şimdi Çok Uzaklarda", Çözülme, İz Yayınları, 2. Bsk., İstanbul, 1993, s. 21.

18 Mustafa Kutlu, "Bir Mektup”, Ortadaki Adam, Hareket Yayınları, İstanbul, 1970, s.75. 
ları, beş pencereli vinçleri ile geldiler, ardlarına dağlardan ovalardan türlü vaadlerle toplanmış bir amele ordusu ile şehrin göbeğinde çadır kurdular. Millet saraçlığı, saatçiliği, berberliği bıraktı, inşaatçı oldu. İnşaat malzemecileri rekor üstüne rekor kırıp, görülmemiş bir maç hasılatı ile keselerini, kasalarını doldurdular. Her kapının her yapının önüne bir Mercedes çekildi. Hüsamettin Efendi ile Hacı Kerim Bey lâhavleler arasında inip binsinler diye..."

Bir kurgu, bir tasarım ürünü olan modern kentlerde planlama gereği birçok meydan bulunmaktadır ancak geleneksel kent anlayışında başat unsurlar olan cami, türbe, hazire bu planlamada önemsenmeyip yerine neonların aldatıcı aydınlığı tercih edilmiştir. Rengârenk neon 1şıkları bir renkte karar kılamayan yanardöner halleriyle modern çağın sembolüdür. Bu 1şıklar gerçeği olduğundan farklı göstererek gerçeklik algımızı değiştirir. Görüntüde pırıl pırıl aydınlatılan ama gerçekte içerisinde yaşayan insanların ruhu karanlığa gömülmüş bir kent gerçekliği önümüzdedir. Gerçeklik algısı değişen insan için gelenek de geleneksel de yabancıdır, ötekidir. Cemal Şakar'ın İhtilaç öyküsünün sonu modern kentlerin nasıl kurgulandığını göstermesi bakımından önemlidir.

"Hemen bir dolmuşa atlayıp terminale gitmeliydim.

Otobüs;

büyük bir şehrin birçok meydanı;

meydanları çevreleyen ne bir cami;

ne bir türbe;

ne bir hazire;

neonların aydınlığ

odam;

masamdaki her şey;

ben ancak böyle bir yerde yaşayabilirim dedim kendi kendime." ${ }^{20}$

Neon lambalarının aldatıcılığını, eşyayı, tabiatı algılama biçimini değiştirdiğini Bu Böyledir'de Mustafa Kutlu da dile getirmiştir: “Lunapark parlyor. Kendinden gayrı her şeyi karartarak. Neonların florasanlarını salgıllyor üzerimize. Onun rengine boyanıyoruz. Yeşil yeşil bakarken birden kıpkızıl ateşle yanıyoruz. Sonra yine mor, yine mor. Her yerden seçiliyor. " 21

Modernizmle birlikte zihinlere yerleşen kent düşüncesi, insan ve toplumu, eşya ve tabiata farklı bakış açısıyla yaklaşan geleneksel şehir düşüncesinden fark-

19 Mustafa Kutlu, Ortadaki Adam, s.75.

20 Cemal Şakar, a.g.e., s. 33.

21 Mustafa Kutlu, Bu Böyledir, Dergâh Yayınları, 11. Bsk., İstanbul, 2012, s. 9. 
l1 bir noktaya savurmuştur. Modernizmin keskin yönleriyle şekil bulan kentler, insandan ve tabiattan kopuk, kurgulanmış yönü ağır basan, tek tipleştirici, farkl11ıklara müsamahasız, kendi renginden başka renklere hayat hakkı tanımayan mekânsal yerleşimler olma özelliği gösterirler.

Modern kentin göstergeleri olan yapılar, kendi varlıklarını göstermenin dışında modern hayatın da gösterenleridirler. Bu yapıların geleneksel dünyaya girişi için, yeni ve güzel bir hayat eşittir modern hayat sloganı eşliğinde kapı çalınır ve dokunduğu her şeyi aynılaştıran bir anlayışla karşılaş1ır. Mustafa Kutlu’ya göre bugün kapitalist sistemin zorladığı tüketim kültürünün esareti altına girdiğimiz için ne merkez ne de taşra hiçbir şey üretmemektedir. Geleneksel şehirlerimiz de birbirinin kopyası bulvarlar, uyduruk parklar, sahil yolları, benzinciler, mobilyac1lar ve apartmanlarla doldurulmuştur. ${ }^{22}$ Modern hayatın boyasını dört bir yana sürmek, gelenekselin bütün ayrılıklarını aynılaştırmak ve bileşik kaplar misali yüzlerce yıldır farklılıkları besleyen birikimden bir çırpıda vazgeçmek anlamına gelmekteydi. Kimliksiz, kişiliksiz yapılar yığınından oluşan kent imgesi bir yanda, bu yığın içinde yeni hayatı bekleyen tüketici kitleleri başka bir yanda beklemektedir. Modern hayatın bizim tecrübemizde karşılığ kent içinde kentler, ayrışma ve çöküntü bölgeleri olmuştur. Mustafa Kutlu'nun dile getirdiği de bu gerçekten başkası değildir. "Apartmanlar ve siteler ile meydana getirilen şehirlerde, âidiyet hissinin oluşmadığ bilinen bir gerçektir. Günümüzün modern denilen uydu kentlerinde veya toplu konutlarda mahalle kurgulanmadığında ve alternatif çözüm getirilmediğinde artık toplumsal ayrışma ve yabancılaşma başlamaktadır."23

Kentleşmenin tavan yaptığı durumlarda geleneksel insan davranışlarının eskisi gibi olması beklenemez. Çünkü kent kendisine uygun davranış modellerini de beraberinde getirir. Geleneksel değerlerle yoğrulan, işini, düzenini, vaktini, saatini ona göre ayarlayan insan yoktur artık. Kentin geçer akçesi ne ise ona uygun davranışlar, meslekler seçer hale gelen insan vardır. Mustafa Kutlu'nun Ortadaki Adam hikâyesinde bu dönüşüm anlatıcı tarafından şu şekilde aktarılır:

"Bir şeyler oldu bu şehre. Daha dün körüğünün başına:

"Dükkan kapısı hak kapısıdır, hakka yalvar

Çeşmim gibidir, akmasa da damlar."

İbaresini asıp, her akşam koltuğunun altında bir karpuz, bir kırmızı mendille düğümlenmiş iki tane taze ikinci ekmeği ile selamlar-aleykümler arasında çarş1dan çıkıp akşam namazına mescide gelen bakırcı Abbas Usta neden bıraktı o gül gibi işi de yetmişinden sonra inşaatçılığa başladı?"24

22 Mustafa Kutlu, Anadolu Yakası, Dergâh Yayınları, İstanbul, 2012, s. 129-130.

23 Mustafa Kutlu, Nur, s. 85.

24 Mustafa Kutlu, Ortadaki Adam, s. 75. 
Kent yaşamı, gündelik yaşama serpiştirilmiş rutinlerle oluşturulmuş bir yapıdır. Rasim Özdenören'in Çark öyküsünde kentli insanın bir gününe projeksiyon tutulur. Bu projeksiyonda rutine bağlanmış günler kentin ve kentli insanın gerçeğidir. Kent ortamında sabahın erken saatlerinde başlayan koşturmaca, gece yarısı yatakta son bulmaktadır. Ancak süreklilik arz eden kent yaşamının insan üzerindeki etkisi daha kalıcı olur ve bıktırıcı bir hal alır.

“Aceleyle kalkar, lavaboya, banyoya koşar, büyük bir hızla tıraş takımlarını hazırlar, bir yandan da elektrik ocağına küçük bir tas içine tıraş suyu koyar, kendisini handiyse yakalayacaklarmış gibi, o ne büyük bir hızla kahvaltısını yapar, jileti yanaklarının üstünden yılan ıslığına benzeyen cızırtılarla kaydırırdı. Ve sokakta koşar, gazeteciden çabucak bir gazete alır, en hızlı giden aracı yakalar, biner, iner, denizi aşıp karşıya geçer, ordan da başka karşılara.. ve gün boyunca bitip tükenmek bilmeyen bu yolculuğun sonu ancak gece yarısı gelir ve ancak o zaman baygın bir halde kendisini yatağa atar, 1şıklar görününceye dek soluk soluğa uyurdu." ${ }^{25}$

Kent ortamında olup bitenler, bu ortama alışık olmayan insanın yaşama isteğini alıp götürür. Kent yaşamından geriye yılgınlık, korku, tükenmişlik kalır. $\mathrm{Bu}$ duyguları yaşayan insanın toplumla, çevreyle sağlıklı ilişkiler kurması beklenemez. Anomi, yabancılaşma tam da bu vasatta yani insanın yaşamaya dair mazeretsiz kaldığı anda gün yüzüne çıkar. Kentin sürekli soğuk, tekinsiz yüzüyle muhatap olan insan, son noktada "paydos" der. Rasim Özdenören'in Çark öyküsündeki kahramanın durumu da budur: "Bütün bunlara paydos artık! Yaşaması için mazeret aramaktan caymıştı, o koşuşlar, korkular, düşüşler, üşüyüşler tüketmiştir onu, bıktırmıştı. Birdenbire ne yaptığını düşündü. Ne yapmıştı! Ne yapmıştı! Binlerce şu kadar günlük ömrü boyunca hep o gicırtılı tramvaylarda, durmadan adını heceleyen trenlerde..." 26

Kentleşmenin sarsıcı hızı ile iç çatışmalar yaşayan, bunalım geçiren, krizlerle boğuşan ve yabancılaşan bireyi, toplumsal çözülmeyi İslamî duyarlılı̆̆ı referans alan öykücülerde de görürüz. Bu birey farklı etkenlerle kente gelmiş ama kente uyum sağlayamamış, kentin merkezinden uzakta, kentin kıyısına, köşesine tutunmaya çalışan bireydir. Köyden getirdiği geleneksel değerler bir tarafta, kentte tanıdığı modern değerler başka bir tarafta durmakta birey ise bu iki değer arasında bir yerde bocalamaktadır. Kentin kalabalığı, atmosferi, gürültüsü, hızı, bireydeki yalnızlık, yabancılaşma ve bocalamayı artırmaktadır. Kent atmosferi özgürlüğün doyasıya yaşandığı bir atmosfer olarak bilinir. Geleneksel değerlerin, hızla değişen kente uyum sağlaması beklenemez. Kentleşme sürecinde en çok yara alan

25 Rasim Özdenören, “Çark”, Hastalar Işıklar, İz Yayınları, 4. Bsk., İstanbul, 1998, s. 9-10.

26 A.g.e., s. 10. 
kurumların başında gelenek vardır. Geleneğin etkinliğini yitirdiği toplumlarda bireyin yabancılaşması, bunalım yaşaması kaçınılmaz hale gelir.

Modernizmle şekillenen kentte insan silikleşmiş bir figür durumundadır. Hiçlik duygusu insanı esir almış, bunalımın eşiğine getirmiştir. Modern kentin yapıcısı insan olmadığı için, yabancılaşma doğal olandır. Şehir ise doğal yollarla oluşmuş, insanı ötelemeyen, kurum ve kuruluşlarıyla insan için var olan, gelenekle birlikte yoğurulan medeniyetin izdüşümünü temsil eder. Mustafa Kutlu'nun Gönül İşi hikâyesinin kahramanı Cenani'nin kent ortamında düştüğü durum bu yabancılaşmayı örnekler niteliktedir:

"Bir müddet kapının önünde durup gözlerini gelip geçen insanların, koca koca binaların, arabaların üzerinde dolaştırdı. Hangi yöne gideceğini hesaplamadan adımlarını kendi başlarına bıraktı. Dört yol ağzına gelip durdu. Bir taksi geçerken üzerine çamur sıçrattı. Bir adam sazına çarptı. Üşüyen insanlar paltolarına sarılarak, evlerine, sıcak odalarına yollandılar. Kirli şehir kuşları gittikleri yerlerden dönüp resmi binaların isli çatılarına kondular. Ferah Sineması'nda çalışan iki çocuk gelip dört yol ağzındaki afişleri değiştirdiler. Üç gün sonra gelecek 'Cem Karaca ve Kardaşlar' topluğunun resimlerini astılar. Cenânî bir müddet bu afişlerdeki saçları sakalları birbirine karışmış, ellerinde görüp tanıyamadığı garip çalgılar tutan adamlara baktı. Çukurçimen yaylasında Hacı İdris'in hanında, bozbulanık bir gecede çalıp söylediği türküleri, ocakta çıtır çıtır yanan meşe kütüklerini, yüzlerinde esrarlı bir suskunluk ile kendini yarı geceye kadar dinleyen köylüleri hatırladı. Bir de araba tekeri değmemiş dağ yollarını..."27

Kentler her zaman bütün unsurlarıyla karmaşık bir yapı arz eder. İnsanın labirenti andıran bu yapıda yolunu bulması, şaşırması, güçlük çekmesi normaldir. O, kırın ucu bucağı, ufuk çizgisi belirli, dingin ortamına alışıktır. Onun alışık olmadığı kendisine yabancı unsurlardır. Kentin kaotik ortamı farklılığa, yabancılığa zemin hazırlar. Kentlerin ağır şartlarına ve karmaşasına uyum sağlama telaşındaki insan, Mustafa Kutlu'nun Yokuşa Akan Sular hikâyesinde anlatıcının ağzından şöyle verilir:

"Gece vardiyası boşanacak. Sil gözlerini. Karşıda bütün farlarını yakıp uluyan, düğmeleri levyeleri ve olanca dişlileri ile bilenip seni bekleyen fabrikaya koş. Kaderini kucakla. Tüylerin diken diken olurken sarıl o soğuk demirden yabancı kadınlara. Motor sesleri ile sarhoş, çarklardan, kayışlardan dökülen nağmelere kapıl. Metal parıltısı karışsın gözbebeklerine, kanlı kanlı bak. Elindeki anahtarın ismi gâvurcadır ezberle. Bu efsunkâr gece uzar gider yıldızlara kadar. Düş içine, düş içinde." ${ }^{28}$

27 Mustafa Kutlu, Gönül İşi, Dergâh Yayınları, İstanbul, 1974, s. 50-51.

28 Mustafa Kutlu, Yokuşa Akan Sular, Dergâh Yayınları, İstanbul, 2001, s. 8-9. 
Kentin gündelik yaşamı bile modern ilkelere göre oluşturulmuş bir kurgudan ibarettir. İnsan için, geleneksel dünyasını var eden, gündüzü ve gecesi belli bir Müslüman Saatinden gecesi gündüzü çalışmaktan ibaret olan, kapitalist mantığa göre oluşturulmuş, öze yabancı bir saate geçiş ne hazindir. İnsanın fizyolojisi, kimyası bu saat yüzünden ayar tutmaz hale gelir. Bu acımasız şartlar ve çarklar altında geleneği hatırlatan küçücük unsurları hayal edebilmek dahi imkânsızdır. Yokuşa Akan Sular'da bir şekilde kent yaşamına tutunmaya çalışan, kırdan kente yeni gelmiş olmasına rağmen kıra özlem duyan kahramanın durumu anlatılır: "Sakın altıotuzbeş trenini unutma. Koşacaksın. Nefes nefese kalacaksin. Siren sesleri ile ürpereceksin. Vinçlerin boşlukta sallanan pençelerinden kan damlayacak. Saçlarında demir tozları. Artık başkalarını istesen de düşünemezsin. O rüzgârda sallanan türküleri. Sıcak tandır ekmeğinin üzerine cızırdayan tereyağını, yayıktan boşalan ayranı, kınalı elleri." ${ }^{29}$

Namaz, cenaze, boyuna asılı hamayıl, yavukludan hediye çevre, geleneksel dünyada karşılığı olan unsurlardandır. Ancak modern dünyanın insanı ezen çalışma koşullarında bunlara yer yoktur. Modern dünyanın kapitali yücelten sistemini kuranlar, şartlarını da belirlemişlerdir. Bu düzeni değiştirme gücü modern dünyayı kuranlardadır. Sözü edilen düzen bütün dünyanın genel gerçekliği haline geldiği için modern dünya, şartlarını değiştirmeyecektir. Dünyasını değiştirerek değerlerinden taviz verecek olan, insandan başkası değildir. Dolayısıyla hem kentte yaşamak, hem şartlara uyum sağlamak hem de geleneksel değerleri yaşamak büyük bir çelişkiyi beraberinde getirir. Mustafa Kutlu'nun Yokuşa Akan Sular'daki kahramanı böyledir: "Unut sabah namazında safta durmayl. Nöbettesin. Unut amcaoğlunun cenazesini, fazla mesai. Boynundaki hamaylı çöz at, güldürme kimseyi yavuklunun verdiği çevreyi göstererek. Bak eller dünyayı değiştirmişler, sen de değiştir dünyanı. Yarınlar senin." ${ }^{30}$

Modern kent, insanî olmayan bir zemin üzerinde yükselmiş ve kendi insanını yaratmıştır. Dolayısıyla modern kent ortamı insan merkezli kurulmadığı için insanı bozmakta, ona iyi gelmemekte, onda kendisine ve çevresine yabancılaşma duygusu uyandırmaktadır. Geleneksel kent, insanı değiştiren, kendisine yabancılaştıran bir yapı değildir. Geleneğin kentinin, insanı ferahlatmak, insanın kendisini ve çevresini tanıması için menfezler açmak, öte dünyayla da ilgi kurmak gibi bir misyonu vardır. Kentler inşa edilirken hep bu misyonun göstergeleri olarak inşa edilmişlerdir. Bu amaçla mekânlar yükseltilirken, yer yurt kurulurken düşünceden plana, plandan yer seçimine, yer seçiminden malzeme seçimine kadar her bir hususa dikkat edilmiştir. Kentin insanı bozan yönleriyle ilgili Mustafa Kutlu, Ortadaki Adam hikâyesinde anlatıcıya şunları söyletir: 


\begin{abstract}
"Çok çeşitli erkekler dinlemişti. Arkadaşının parasızlık sızlanmalarını, âmirin aldatıldığını, memurun hakkının yendiğini, işçinin ezildiğini, bakkalın doymadığını, kasabın geçinemediğini. Oysa biliyordu kendi cebinden son on lirasını verirken arkadaşının cebinde yüz lira olduğunu. Âmirin kumarda kaybettiğini, memurun her gece kafayı çekip karısını döğdüğünü, işçinin her gece cüzdanına ters orantı teşkil eden bir pavyona dadandığını. Kasabın etini, bakkalın sütünü, bile bile dinlemişti. Bütün huzursuzluklar şehirlerin geniş dünyasına açllıyordu. Hayatını değiştirmesi gerekliyse, önce değerler sitemini değiştirmeli idi. Şehirlerin her yeniliği yeni bir istemeye yol açıyor, tatminsizlikler gerisi de bildiğiniz gibi..."
\end{abstract}

Modernizmin, kent yaşamıyla getirip yerleştirdiği değerler sisteminin insanı çaresizlik içine düşürdüğü ve bu çaresizlik halinin kocaman bir heyula gibi bireyin karşısında durduğu gerçeğini değiştirmek olanak dışıdır. Modern kent yaşantısı, insanı değer yitimine uğratır. Burası insanın sağlıklı ilişkiler kurabileceği ve sürdürebileceği sahil-i selamet bir alan değildir. Dolayısıyla hızla değişen, dönüşen, "yaşamın her defasında altüst olduğu, karışık bir dünyaya ait maddi ve manevi bir yaşama örüntüsünü oluşturabilmek, son iki yüzyllın en büyük sorunudur."32

Geleneksel hayatın dinamikleri kent ortamında bir bir kaybolmaya yüz tutmuştur. Din, dinin getirdiği kurallar zinciri aşınmaya başlamıştır. Sevgi, saygı, merhamet kentin değerleri değildir. Metropolün tek geçerli değeri, işlem arac1 paradır. Para hırsı, insanı insanın kurdu yapmış, insan en yakınını dahi tanımaz olmuştur. Bugün insanların kahir ekseriyeti için yaşam alanları olan metropol "şehirlerimiz ileride daha az yeşil daha az tabiat, daha az sükûnet ve buna karşın daha çok yol, daha kalabalık nüfus, daha çok endüstri, daha kirli hava, daha kirli deniz, daha çok koşuşturmaca ile dolu olacak" ${ }^{\prime 3}$

Metropol kimlikli kentlerde insanın kendi kalması, gelenekle bağ kurması neredeyse olanaksız kılınmıştır. Mekân, bir yönüyle insanın var olması anlamına gelir; metropolde bu varlık durumunun incindiği, yaralandığı söylenebilir. Çünkü metropolün öznesi insan değildir, metropolün öznesi paradır, piyasadır. Metropolde özne çoğuldur, melezleşmiştir. Bu ortamda "hızlı yaşamanın, metropollerin, yüksek binaların, gürültünün, asayiş sorunlarının, tabiattan uzak kalmanın, ruh sağlı̆̆ın iyicene tehlikeye attığ "hayat tarzl" karşısında" 34 kimlikler, kişilikler, karakterler birbiri içine geçmiştir. İnsan bu çoğul kimlikler arasında adeta kimliksiz kalmıştır.

31 Mustafa Kutlu, Ortadaki Adam, s. 48.

32 Hakk1 Yırtıc1, a.g.e., s. 3-4.

33 Mustafa Kutlu, Nur, s. 83.

34 Mustafa Kutlu, Vatan Yahut İnternet, Dergâh Yayınları, 4. Bsk., İstanbul, 2016, s. 86. 
Kimliklerin, kişiliklerin birbiri içine geçtiği böylesi bir zamanın öykülerinden birisi de Cemal Şakar'ın Mutfakta Bir Öykü'südür. Öyküde, beyaz yakalılar diye nitelendirilen sınıftan, bir plaza çalışanı olan Necla'nın yaşamına dair kesitler buluruz. Öykünün kahramanı Necla, "plazanın yüksek katlarından birinin steril tuvaletlerinde (...) klozete eğilmiş ögüre ögüre kus"maktadır, yardımcısı (olan) Asistan (kız) (Necla'nın) çanta(sını) toplarken masanın üzerinde antidepresanı görü(r)." ${ }^{35}$ Öykünün bir cümlesinden bile insan ve mekân unsuruna ait birçok bilgi çıkarılabilir.

1950'lerden 2000'lere uzanan süreçte geleneksel evler bir bir terk edilmiş, apartmanlar yaşama mekânı olarak seçilmişti. 2000'lerden sonra ise sayıları hızla artan gökdelenlere, cam binalara, plazalara ve rezidanslara doğru bir yöneliş vardır. Zaman geçmekte, mekân değişmekte mekânla birlikte insan da değişmektedir. Dolayisıyla muhatap olunan yeni hayat tarziyla yeni bir insandir. Bu insan yüksek katlı plazalarda çalışmakta, yine yüksek katlı bir rezidansları mesken edinmektedir. Cemal Şakar'ın Bir Tip öyküsünde bu duruma dikkat çekilir: Asistan kız "Necla'yı kaçırırcasına plazadan çıkar[ır], taksiye atıp rezidansın yüksek katlarından birindeki $1+0$ dairesine" ${ }^{36}$ götürür. Çantadan çıkan antidepresan yeni insanın ruh durumuyla ilgili ipuçları sunmaktadır. Yeni zamanın yeni insanı yalnızdır, yabancıdır. Değerlerini bir bir yitirmiş modern kentli birey, krizlerine ilaçlarla çözüm aramaktadır. Yaşanan, çözümleri yine kriz ve bunalımda bulan paradoksal bir süreçtir. Kentli bireyin zamanı ve mekânı karamsarlıkla kuşatılmıştır. Modern kentin kalabalığı, gürültüsü, karmaşası arasında çıkış yolu bulamayıp bunalan insan profilinin kendine, topluma yabancılaşması, kurallara uymaması, sürekli bir şeylerin eşiğinde, arayışında bulunması beklenen bir durumdur. Asistan kızın gözünden verilen aşağıdaki oda tasviri ve beraberinde akla gelen sorular modern çağa ait ipuçları açısından önem taşır:

"Duvardaki fotoğraflar, afişler asistanın canını yaklyor, kaldıramıyor bu sertliği ve anlayamıyor Necla Hanımın nerelerde ne aradığını, neden kendisi gibi kariyer sahibi biriyle evlenip mutlu mesut yaşamadiğını... Tanışalım-buluşalım sitelerinde kimlerle tanıştı̆̆ını, kimlerle buluştuğunu hayal etmeye çalışıyor bu yüksek kattan karşı pencerelere bakarken... Hayal dahi edemiyor... Sonra aklına Necla hanımın tenindeki izler geliyor, ürperiyor, korkuyor erkekterten..." ${ }^{37}$

Stüdyo dairede oturmak, ilişkilerini gerçek hayattan değil de sanal âlemden, tanışalım buluşalım sitelerinden seçmek, antidepresan kullanmak, tüketmek kentli bireyin rutini haline gelmiştir. Ne geçmiş, ne gelenek onun için bir şey

35 Cemal Şakar, “Mutfakta Bir Öykü”, İtibar, Say1: 52, Yı1: Ocak 2016 (18-20), s. 18-19.

36 A.g.e., s. 19.

37 Cemal Şakar, a.g.e., s. 19. 
vadetmemektedir. Geleneğin dünyasında insanın kenti söz konusu iken, modern dünyada kentin insanından söz etmek daha doğrudur. İnsanı merkeze alan, onun varoluşsal güveninin ve derinliğinin aksettiği, inancın yapıtaşı olduğu, manevi olarak dikey, maddi olarak ise yatay tekâmülü esas alan şehirlerdir insanın şehirleri. Hacı Bayram'ın "Nâgihân ol şara vardım ol şarı yapılır gördüm/Ben dahi bile yapıldım taş u toprak arasında" diye ifade ettiği bir şehirdir bu. İnsanın yaptığı ama aynı zamanda kendisinin de yapıldığ 1 , karşılıklı bir bağın, ünsiyetin gerçekleştiği şehirlerdir bu şehirler. İnsan maddi olarak bu şehri imar ederken manevi olarak da kendisini inşa eder. Kentin insanının ise hayat tarzı, giyimi, yiyip içtikleri, ilişkileri yeni mekânsal örgütlenmeler eliyle belirlenmektedir. Gökdelenler, cam binalar, rezidanslar, siteler, kent çevresine konumlanan küçük kentler, bu mekânsal örgütlenmelerin görünen yüzleridir. 


\section{Sonuç}

Kentleşme ve kentlileşme kavramları, modern kent anlayışıyla yaşamımıza dâhil olmuştur. Öykü türü de bir yönüyle modern Türk edebiyatının -her ne kadar güçlü bir tahkiye geleneğinin üzerinde yükselse de- yeni türlerinden biridir. Öykünün Türk edebiyatında ortaya çıkışından bu yana kent, öykünün ana mekânıdır. Öykü nitelik itibariyle de kentli bir türdür. Ancak ilk öykü örneklerinde kentin öyküye mekân olması daha çok dekor teşkil etme anlamındadır. Kente ait dikkatler, bireyin bunlar karşısındaki durumu ilk örneklerinden 1950'lere kadar, öyküde çok yer almaz. Dikkatlerin kente çekilmesi için 1950 ve sonrasını beklemek gerekecektir.

1950'den sonra Türkiye'de siyasal ve sosyal ortamın değişmesi, birçok alandaki dönüşümler için de kapı aralar. Çeşitli sebeplerle kırsal alanlardan kentlere göçlerin yoğun biçimde başlaması, önce kentlerin nüfus yapısını, ardından da mekânsal yerleşimini değiştirir. Kentlerde nüfus ve konut sayısının nicelik olarak artışı, kentleşme sürecini beraberinde getirir. Kentleşmenin ardından, sonradan kent bünyesine dâhil olan bireyin uyum süreci başlar.

Öykücü için malzeme oluşturan, temel problem tam da buradadır. Bireyin kentleşmeye verdiği tepkiler, kentli değerleri içselleştirip içselleştirememesi, kentte değer yitimine uğraması, yalnız kalması, kendisine ve topluma yabanc1laşması izlekleri, 1950 ve sonrasında öykücüler için zengin bir içerik sunar.

50 kuşağ1 öykücüleri ve onlardan sonra gelen öykücüler bu malzemeden faydalanmışlardır. 1970'li yıllarda Necip Fazıl çizgisini devam ettiren, Rasim Özdenören, Mustafa Kutlu gibi İslamî duyarlığa sahip öykücüler de kent, kentleşme, kentlileşme ve bireyin bu kavramlar karşısındaki tavrı bağlamında ortaya çıkan problemin öykülerini vermişlerdir. Kentleşme, kentlileşme bahsi Türkiye ölçeğinde henüz tamamlanmış bir süreç değildir. Dolayısıyla bu sorusal, her dönemde öykücü için değerlendirilebilecek bir temadır. 1980'lerde öykü serüvenine başlayan Cemal Şakar da öykülerinde insan gerçeğinden yola çıkarak kentleşme, kentlileşme meselesine değinir. Ancak 1970'lerde hılı kentleşme be beraberinde kırsaldan göçen insanın kente uyum problemi sorun teşkil ederken günümüzde kentleşme ve kentlileşmenin farklı, yeni bir boyutuyla karşı karşıya kalınır. Bugünün öykülerinde, cam binalar, rezidanslar, plazalar, siteler yaşama veya çalışma mekânı olarak sunulmakta, buradaki insanın sorunları da problem alanı olarak gösterilmekte ve ona uygun öyküler kaleme alınmaktadır.

İslami duyarlılığı öne çıkaran öykücülerin bazıları yer yer 50 kuşağı öykücüleri gibi varoluşçuluğun argümanlarını kullansalar da, varoluşçuluğun çıkmaz sokaklarına sapmadan kentleşme, kentlileşme sorunsalı karşısında insanın ve toplumun açmazlarını irdelerler. Rasim Özdenören, Mustafa Kutlu, Cemal Şakar, öyküleriyle kentleşmenin ağır sonuçlarını, insanın kent ortamında bu ağır 
sonuçlarla başa çıkamadığını, kendini ve değerlerini yitirdiğini göstermişlerdir. Modern kentin problem yumağ 1 haline gelmiş insan ve toplumuna, geleneksel değerleri bir çıkış yolu olarak sunarlar. İnsanın varlığ 1 ve kutsal nazarındaki konumu gelenekte tarif edildiği gibi algılanmadığında kentleşme ve kentlileşmenin getirdiği problem alanlarına, doğru çözümler üretmenin de zorlaşacağını söylerler. Çünkü geleneğin inşa ettiği kent ve içindekiler, en değerli varlık olan insan içindir. Modernleşmenin daima şimdiyi gösteren algısında ise başat unsur, kentin göstergeleriyle, havasıyla, mekânlarıyla bizatihi kendisidir. İnsan, kent mekânlarını deneyimleyen bir figürden öteye gitmez. Kent kentleşme, kentlileşme olgularının Türk öykücülüğünde bir problem alanı olarak değerlendirilip öyküye yansıtılması bağlamında geleneğin hâkim olduğu zaman dilimlerinde kentin gelenekle bağ kuran insan tarafından şekillendirildiği, 1950 sonrasında ise kentin geleneği ve insanı dışlayan modern değerler çerçevesinde ele alındığı ortaya çıar. 


\section{Kaynakça}

And1, M. Fatih, "Beton Duvarlar Arasında Açan Çiçek: Modern Kent ve Kentleşmeye Karşı Erdem Beyazıt'ın Şiiri”, FSM İlmî Araştırmalar İnsan ve Toplum Bilimleri Dergisi, say1 1, Bahar 2013.

Alver, Köksal, "Toplumsal Değişme ve Öykü”, Hece Öykü, sayı 12, Aralik-Ocak 2005.

Arendt, Hannah, Geçmişle Gelecek Arasında, çev. Bahadır Sina Şener, İstanbul, İletişim Yayınları, 1996.

Barak, Burhan, "Yaz Geldi mi”, Dergâh, sayı 293, Temmuz 2014.

Bulut, Şevket, "Eski Toprak”, Dilek Çınarı, İstanbul, Türk Edebiyatı Yayınlar1, 1975.

Dellaloğlu, Besim F., "Kent Öznenin Evidir”, 21. Yüzyıl Karşısında Kent ve Insan, yay. haz. Firdevs Gümüşoğlu, İstanbul, Bağlam Yayınları, 2001.

Harvey, David, Sosyal Adalet ve Şehir, çev. Mehmet Moralı, İstanbul, Metis Yayınları, 2003.

Kıray, Mübeccel, Kentleşme Yazıları, İstanbul, Bağlam Yayınları, 1998.

Kutlu, Mustafa, Ortadaki Adam, İstanbul, Hareket Yayınları, 1970. , Anadolu Yakası, İstanbul, Dergâh Yayınları, 2012. , Bu Böyledir, 11. bs., İstanbul, Dergâh Yayınları, 2012. , Gönül İşi, İstanbul, Dergâh Yayınları, 1974. , Nur, İstanbul, Dergâh Yayınları, 2014.

, Vatan Yahut İnternet, 4. bs., İstanbul, Dergâh Yayınları, 2016. , Yokuşa Akan Sular, İstanbul, Dergâh Yayınları, 2001.

Önertoy, Olcay, Cumhuriyet Dönemi Türk Roman ve Öyküsü, İstanbul, Türkiye İş Bankası Kültür Yayınları, 1984.

Özdenören, Rasim, Çözülme, 2. bs., İstanbul, İz Yayınları, 1993. , Hastalar Işılklar, 4. bs. İstanbul, İz Yayınları, 1998.

Özer, Sevinç, “1960’tan Bu Yana Roman ve Kisa Öyküde Kentleşme Olgusu ve Kentlileşme Sorunları”, Yazko Edebiyat, sayı 32, Haziran 1983.

Şakar, Cemal, "İhtilaç", Hece Öykü, sayı 1, Şubat-Mart 2004.

Tanpınar, Ahmet Hamdi, "Hikâye ve Roman", 19'uncu Asır Türk Edebiyatı Tarihi, İstanbul, Çağlayan Kitabevi, 1997.

Yırtıc1, Hakkı, Çağdaş Kapitalizmin Mekânsal Örgütlenmesi, İstanbul, İstanbul Bilgi Üniversitesi Yayınları, 2005. 
